UDC 81'4. 81'42. 81'23. 37

DOI https://doi.org/10.32841/2409-1154.2021.48-1.14

Dobosh O.S.,

English Lecturer at the Applied Linguistics Department Lviv Polytechnic National University

\author{
Albota S.M., \\ PhD in Philology, Associate Professor, \\ Associate Professor at the Applied Linguistics Department \\ Lviv Polytechnic National University
}

\title{
DISCURSIVE AND METAPHORICAL FEATURES OF THE "BREXIT" CONCEPT
}

Summary. The paper focuses on the construction of a metaphorical conceptual BREXIT model in political discourse. Having analyzed the theoretical principles of conceptual game theory and conceptual metaphor, the BREXIT concept is discovered within the research scope of sports. Conceptual game theory has fostered the process of comparing the BREXIT concept with a sports game taking place on a sports field, whereas the political course is aimed at deployment in the political arena. We claim that the BREXIT concept is revealed through the SPORTS concept. Based on online sources such as blogs with political discussions, business booklets and the diversity of the British press, namely, The Telegraph, The Irish Times, Financial Times, Farmers Guardian, Daily Record, The Guardian (2017-2020) with extensive political comments, stylistic and semantic analysis was conducted. Moreover, a careful interpretation of the metaphorical and discursive features of the BREXIT political concept was provided. These peculiarities are considered through detailed interpretations of a number of the allocated metaphors with a combination of such stylistic devices as allegory, symbolism, exaggeration and simile. Having conducted the analysis, an inner structure of the metaphorical cognitive BREXIT model was regarded. It was proved that the basic conceptual BREXIT model consists of cognitive frames (INDIVIDUAL SPORT, TEAM SPORT and TRACK EVENT). Each of them, respectively, is divided into cognitive slots. The main slots had a more detailed division into other slots, namely: the first cognitive frame INDIVIDUAL SPORT is represented by a single cognitive slot-BOXING; the second cognitive frame TEAM SPORT is metaphorically manifested in the first cognitive slot BALL GAMES with its subdivided slots: FOOTBALL and BASEBALL, and the second cognitive slot WATER SPORTS without additional subdivision; the third cognitive frame TRACK EVENT is embodied by two cognitive slots, namely: RUNNING EVENT and TRECKING. Discursive and metaphorical features of all these components were considered.

Key words: metaphorical conceptual model, BREXIT concept, SPORTS concept, political discourse, metaphor, conceptual game theory, cognitive frame, slot.

Formulation of the research problem. Metaphorical images triggered by existing conceptual game theories have recently become a sphere of contemporary linguistic findings. Highlighting main theoretical studies concerning concepts, metaphorical images, cognitive frames has fostered the deployment of particular research aspects. Thus, the research relevance is substantiated by discovering discursive and metaphorical features of the BREXIT concept involving its cognitive frames with metaphorical manifestations in terms of cognitive linguistics, psycholinguistics as well as social linguistics. The study is based on politically-oriented web news blogs, business guides and publications in The Telegraph, The Irish Times, Financial Times, Farmers Guardian, Daily Record, The Guardian (2017-2020) and their commentaries.

It is widely regarded that our system of concepts is contemplated and formed by metaphors. Some prominent scholars believe that the reason of it is the fact that the world images and realia are frequently conceptualized through metaphors. According to Z. Kövecses, a type of conceptual metaphor is manifested in text or discourse as an integral system of metaphorical models [1]. Such an approach was theoretically applied into the conceptual blending according to [2]. The latter theory discloses the procedure of shaping contemporary meanings within a new metaphorical textual structure owing to G. Lakoff [3; 4]. In the opinion of N. Mishankina, these models have immense prospective in language implementation varying from traditional lexical and semantic ranging to discourse or textual formation [5].

The theory of conceptual metaphor, around which neural theory of metaphor is involved, is visualized more as a mapping between frames than domains. The technique of mapping is of neurophysiological nature which consists in interrelated activation of neural zones [6]. The frame is considered to be a network of slots meaningfully connected. Such interwoven 'links' account for irreparable structures of knowledge representation [7]. What concerns frame structure, it resembles speculations upon human conceptualization of the picture of world as well as linguistic input both grammatical, e.g. [8; 9], and lexical [10] levels. Modern approaches to Conceptual Metaphor Theory $[3 ; 4]$ crucially promote frame structure in terms of detailed discovery of metaphor. Despite a variety of contributions implying cognitive neural framing peculiarities within the scope of research belonging to neuropsychologists, the study of inner linguistic framing still constitutes an exploring ground for revealing metaphoric embodiment of the relations between psychological discursively cognitive frames.

Outlining the main findings of the research. What is commonly known is the fact that the UK is renowned for its precious autonomous patterns referring to people being promoted to election process. However, political discourse inclusions prevail there as well. We claim that such political 'competitions' are the only 
'sport' (hereafter as sport) domains in terms of British participation and involvement. Now, we balance both notions, therefore, sport may be referred to the same extent as the politics with regard to Britain realia. People there do not necessarily take routine at ease. Each life aspect concerns 'competitions', as psychological and linguistic perception of such conceptual area is 'winningorientated'. In attempt to prove theoretical background, one may usually face the usage of the following sport (=political) metaphors: to fight and compete with the opponents embodying semantics of politic campaign to oppose in order to gain the desirable effect, or to win an election implying the same semantics of winning process or a result of overcoming the opposition obstacles. Treating business like a part of politics, there is a common metaphor beat one's competitors to survive with semantics of winning process as well but with deeper sense implications.

Being one of the recently appeared British linguistic and political notions, Brexit as a term has been bombarded with diverse approaches to its discovery, mainly its metaphorical nature [11]. The purpose of the paper is to analyze and reveal cognitive nature of the BREXIT through its manifestations within modern political discursive and metaphorical peculiarities involving 'sport' cognitive frames.

Outlining the main findings of the research. Since the concept of BREXIT is deployed through metaphorical frames, here we resort to the comparison of the political phenomenon with sporting techniques and events metaphorizing political arena into the sports field.

In order to analyze the discursively metaphorical features of the mentioned concept, let us consider a dominant metaphorical model - BREXIT IS SPORT - within the political and sport discourse. It provides a multidisciplinary apprehension of the process of elimination of cognitive perceptions between the UK from the EU patterns and frames.

The stated BREXIT model involving metaphoric manifestations is revealed by such cognitive frames as INDIVIDUAL SPORT, TEAM SPORT AND TRACK EVENTS. Each of the presented cognitive frames consist of slots, deeper metaphorical implications of the concept. We choose the following slots to serve a function of discursive markers outlining various connotations as well as semantic implications and explications.

The first cognitive frame to consider is INDIVIDUAL SPORT. It is embodied by the single slot BOXING. The international application of governmental metaphors involving the process of box is peculiarly substantiated by the inner linguistic senses of the sports notions. For instance, such collocation as 'the spirit of competition' implies the semantics of victory through mean battles and overcoming opposition. Apart from inner, or hidden implications, there are those referring to the process of box battles and regulations within them, e.g., such connotative meanings as break and rest refer to the sporting noun round, or a range of verbal embodiment resembled by fail, beat and defeat is involved in the semantics of sporting term knockout. In comparison with sporting semantics, political ambiguity is realized through metaphor knockout blow implying the sense of political or business failure without a possibility to regain. Metaphors of sports events embrace the semantics ofdisapproval, eloquenceand controversies concerning the winning process - victory. Thus, disputable questions arise around their contradictory nature, which is found in the following newspaper headlines: "Boris Johnson's red lines prove he is going for a second round Brexit knockout" (https://www.telegraph. co.uk/politics/2020/02/28/boris-johnsons-red-lines-prove-goingsecond-round-brexit-knockout), "UK must suffer knockout blow if EU is to thrive" (https://www.irishtimes.com/opinion/uk-mustsuffer-knockout-blow-if-eu-is-to-thrive-1.4088418), "Britain is stumbling into a knockout blow" and "We have been punching above our weight for years but our competitors are getting heavier, warns John Marriott" (https://www.theguardian.com/politics/2017/ jun/15/britain-is-stumbling-into-a-knockout-blow). One of the newspaper headline's phraseological unit punch above one's weight has a correspondence to such compound lexical units from the boxing area as lightweight, middleweight and heavyweight. It is commonly widespread information about the boxers that only one weight category people can be involved into battle. The metaphors stated before refer to the circumstance including the battle of two boxers with different weight categories. Now, to compare sporting situation with political affair, one may state that the above constant unit is claimed positively connotative in terms of assessment. In this way, such discursive marker denotes the political fact that some powerful governors may fulfil their greatest political intentions, thus proving themselves to be stable rulers, whereas others gain only psychological aggressive states. This contradictory debate ignites political controversies and unfair competition.

The second cognitive frame entitled TEAM SPORT embraces both slots BALL GAMES with its subdivided slots and WATER SPORT. A key word within this cognitive perception - game. According to N. Arutyunova, people are succumbed to pursuits involving various entertainment patterns. These so-called games vary in their functions, but their main principles remain competitiveness, fight, overcoming obstacles, victory as in life routine as in other aspects - politics, sports, war [12]. Accordingly, we encounter the situation that the concept of life game has a crucial role not only daily but also it is a pattern which is imposed onto the political arena as well as sporting ground along with their fierce battles and oppositional collisions. As a result, everyone is obsessed with an intention to find their privileged life circumstances.

The first slot of the second cognitive frame - BALL GAMES - is embodied by the subdivided slots of FOOTBALL and BASEBALL. Such a detailed subdivision is characterized by the inner complex football connotations which one may encounter referring to the following newspapers' headlines: "If Brexit were a game of football the score to date would be in own goals only" (https://infacts.org/brexit-goal-score-far/) and "Taoiseach under fire for 'green jersey' demands in Brexit talks" (https://www. independent.ie/business/brexit/taoiseach-under-fire-for-green-jerseydemands-in-brexit-talks-37501414.html). All the stated headlines imply these discursive markers denoting the deployment of the first subdivided slot (FOOTBALL). What is of interest - the last phrase green jersey - has become a metaphorical expression of the BREXIT concept. The term has its history from Irish football team. Nowadays, its inner sense is underlying the fact that politicians adhere to the rules of laissez-faire policy in order to remain innocent in case of being blackmailed or attacked. What is more derogatory is the political fact that Ireland failed to support Brexit. Additionally, previous newspapers' linguistic markers allow to state the BREXIT concept is often revealed by sport metaphors aiming at the election's outcomes as well as it may be referred to a football score.

The second subdivided slot (BASEBALL) may be represented by such common sport metaphors as to step up to the plate implying the personal own efforts to succeed, to prove your own assertiveness 
in front of everyone, and playing hardball with the similar meaning but with deep sense connotations of determination and strong willingness to go the mile. "Labour must step up to the plate and end Brexit madness after Tory resignations" (https://www.dailyrecord. co.uk/news/politics/labour-must-step-up-plate-12884993) - a clear case of determination and taking a right political position.

Or even the usage of metaphoric idiomatic expressions may refer to the political discourse of the BREXIT concept: a slow ball with a meaning of performing tricks in order to skilfully deceive the opponent; to swing for the fences denoting all efforts aimed at ultimate challenge (https://www.ft.com/content/2ced55b0fe01-11e8-ac00-57a2a826423e).

What is worth mentioning is that British ball games gained much popularity in. This is a reason why a variety of their awards dominate in ball games. This fact is also reflected in such metaphors as parliamentary ping-pong, score an own goal, home-side goals. They are frequently applied by the media to portray the disputable topics in the British Parliament.

Coming back to the second cognitive frame - TEAM SPORT let us consider the second main subdivided slot - WATER SPORT. Its metaphoric examples comparing Brexit with like white water rafting meaning failure to rule the world or like rafting down a river with an explication of impossible course of actions to overcome the current obstacles (https://www.fginsight.com/brexit-hub/brexit--farmer-comment/brexit-is-like-white-water-rafting-with-a-coxwhos-fallen-overboard-). The vivid metaphorical explications prove the fact that whatever collaborative work politicians have, it requires fair and precise political direction to meet the desirable expectations.

The third cognitive frame - TRACK EVENT - consists of two slots: RUNNING EVENT and TREKKING. If we regard political state of affairs, it is mainly referred to as sports competition represented in a metaphorical way but marked with velocity. The latter is equal to a marathon a runner has to deal with. Treating political campaign in terms of sports interpretation, we imply to track the deployment of political actions, their dynamics as well as to evaluate the political implementation rates.

Regarding the subdivided slot RUNNING EVENT out of the third framing concept, we state that it is compared to political debates at their fast pace, e.g., marathon or sprint. The main rule of any kind of these-be prepared beforehand. Similar to the sporting training and preparation, politically implemented programs have to stick to the same rules. The crucial failures of them are depicted in the following newspapers' headlines: "Are you in training for the Brexit Marathon?" (https://tjenglish.co.uk/latest/are-youtraining-brexit-marathon), "Brexit: a marathon theoretically due to end on 31 December 2020" (https://blog.ibanfirst.com/en/brexita-marathon-theoretically-due-to-end-on-31-december-2020). Or else, in which we find Merkel's metaphorically compared with the sports running events statement about final sprint of Brexit negotiations (https://www.irishtimes.com/news/world/europe/ brexit-negotiations-in-final-sprint-says-merkel-1.4053075). The metaphors stated above impose a challenge upon so-called pro brexiteers as they suggest that even if Brexit is guaranteed, they may go in sport with an aim of becoming skilful enough to be politically aware as well as to become financially fit. Apparently, not taking into account all failures, those, who are in favour of Brexit, are willing to catch an opportunity to become politically fit and start the ball rolling in case of any new challenge.
The second subdivision of slots concerning the TRACK EVENT cognitive frame is TREKKING. The latter involves, as G. Lakoff once mentioned [3], a journey, thus metaphorically implying long process of gaining experience and only after substantial rational baggage - hit the ground. In some news item referring to the concept of BREXIT, its metaphorical feature was evolved into hill walking denoting distraction, relaxation or even a break. The Brexit process is compared with walking in the mountains as before starting off one should keep in mind a set of rules to obey. There is a metaphoric expression for politics matter followed by sports feature - to put one foot in front of the other - with implications of taking considerable measures requiring thoughtful cognitive process to weigh all the pros and cons. Such drastic measures are necessary as it is possible to encounter a steep and rocky path, which one may find dangerous to be involved into. Under these circumstances there is no opportunity but to turn back to the initial phase of political program implementation. Also, we find metaphoric implications of cul-de-sac - falling rocks - if political situation approaches the wrong course, the threat is imminent. The discursive phrase with metaphoric implications of hope for prosperity - keep looking at the summit - calls for not giving up in any situation (https://www.bbc.co.uk/news/uk-politics-40726215).

So, the metaphors mentioned above are not plain in their essence, they combine elements of symbol, allegory, hyperbole, simile, etc. They are mostly connected to sports events and life challenges. The last ones warn about the threat of being hindered by the obstacles, still victory may be achieved at any cost.

Conclusions and prospects for further development. All in all, an attempt to outline a metaphorical concept model of BREXIT was made. It was substantiated that metaphoric images were actualized by conceptual game theories referring mainly to such research area as sport. The scope of our research was determined by political as well as sports discourse. The research material was found in popular newspapers' headlines, web blogs, business newsletters, newspapers' commentaries. As the BREXIT concept was manifested in sporting preferences, only sport metaphors were the object of the research. The concept under analysis was cognitively perceived by not only metaphoric expressions or elements of symbol, allegory, exaggeration or simile. It was also analyzed through discursive markers (words, phrases, collocations, idioms) which helped to outline and denote the general metaphoric model of the BREXIT concept - BREXIT IS SPORT.

Based on the theoretical background of prominent cognitive linguistics, a notion of conceptual metaphor is deployed in our study. The conceptual game theory fostered the process of comparison the BREXIT concept with the sporting game performed on the sports field to the same extent as political course of action was performed on the political arena. A variety of sporting metaphors were provided and analyzed semantically and in interpretative manner. Such thorough analysis served to reveal the inner structure of the stated concept. We proved that the main BREXIT concept consisted of cognitive frames (INDIVIDUAL SPORT, TEAM SPORT AND TRACK EVENTS). Each of them, in their turn, included cognitive slot division. Main slots had subdivided slots. The discursive and metaphoric features of all components stated were considered.

To conclude, the BREXIT concept is embodied by metaphoric and discursive features implying training process of expectations and efforts (via first cognitive frame). Afterwards - through skillful 
selection of political team members and their negotiation abilities (via second cognitive frame). And, finally - lifelong journey of winning process - to achieve the desirable effect including all obstacles, hindering techniques and opponents (via third cognitive frame). It is up to rulers whether they choose to be on the ball, or being taken an eye off the ball to move the goalposts and play a whole new ball game.

In perspective, it is worth revealing other concepts and compare their metaphorical manifestations with the one under analysis within political discourse.

\section{References:}

1. Kövecses Z. Metaphor: A practical introduction. Oxford : Oxford University Press, 2010. 400 p.

2. Fauconnier G. and Turner M. The way we think: Conceptual blending and the mind's hidden complexities. New York : Basic Books, 2003. $464 \mathrm{p}$

3. Lakoff G. and Johnson M. Metaphors we live by. Chicago : University of Chicago Press, 1980. 242 p.

4. Lakoff G. and Johnson M. Philosophy in the flesh: The embodied mind and its challenge to western thought. New York : Basic Books, 1999. $640 \mathrm{p}$.

5. Mishankina N. Metaphorical models of linguistic discourse. Scientific Journal, Tomsk State University Journal. 2009. № 324. P. 41-49.

6. Lakoff G. The neural theory of metaphor. In: R. W. Gibbs, ed. The Cambridge handbook of metaphor and thought. Cambridge : Cambridge University Press, 2008. P. 17-39.

7. Evans V. and Green M. Cognitive linguistics: An introduction. Edinburgh: Edinburgh University Press, 2006. 830 p.

8. Goldberg A. Constructions: A construction grammar approach to argument structure. Chicago: University of Chicago Press, 1995. 271 p.

9. Östman J.-O. and Fried M. (Eds.). Construction grammars: Cognitive grounding and theoretical extensions. Amsterdam : John Benjamins Publishing, 2005. Vol. 3. 325 p.

10. Fillmore Ch. Frame semantics. Linguistics in the morning calm, ed. by The Linguistic Society of Korea. Seoul : Hanshin Publishing Co, 1982. P. 111-137.

11. Альбота С.М., Добош О.С., Сабан О.В. Концептологія природніх стихій у порівнянні з концептом «Брекзит». Наукові записки університету «Острозька академія». Серія «Філологія». Херсон, 2020. Вип. 9 (77). С. 35-39.

12. Arutyunova N. Logical analysis of language: Conceptual game fields. Moscow, 2006. P. 42-59.
Добош О. С., Альбота С. М. Дискурсивні та метафоричні особливості концепту «Брекзит»

Анотація. Статтю присвячено побудові метафоричної концептуальної моделі «Брекзит» у політичному дискурсі. Послуговуючись теоретичними підвалинами концептуальної теорії ігор і концептуальної метафори, концепт «Брекзит» проаналізовано в межах спортивної тематики. Концептуальна теорія ігор сприяла процесу порівняння концепції «Брекзит» зі спортивною грою, яка відбувається на спортивному майданчику, тоді як політичний курс націлений на розгортання на політичній арені. Стверджуємо, що концепт «Брекзит» розкривається через концепт спорту. На основі таких інтернет-джерел, як блоги з політичними дискусіями, бізнес буклети й різноманіття британської преси, а саме: The Telegraph, The Irish Times, Financial Times, Farmers Guardian, Daily Record, The Guardian (2017$2020)$ - 3 розлогими політичними коментарями, проведено стилістико-семантичний аналіз і здійснено ретельну інтерпретацію метафоричних і дискурсивних особливостей політичної концепції «Брекзит». Ці особливості виявлено шляхом детальних трактувань низки виокремлених метафор із поєднанням таких стилістичних засобів, як алегорія, символізм, перебільшення та порівняння. За допомогою проведеного аналізу досліджено внутрішню структуру метафоричної когнітивної моделі «Брекзит». Доведено, що основна концептуальна модель «Брекзит» складається 3 когнітивних фреймів («Індивідуальний вид спорту», «Командний вид спорту» й «Бігові змагання»). Кожен із них, відповідно, поділяється на когнітивні слоти. Основні слоти мають більш детальний поділ на інші слоти, а саме: перший когнітивний фрейм «Індивідуальний вид спорту» представлений єдиним когнітивним слотом - «Бокс»; другий когнітивний фрейм «Командний вид спорту» метафорично проявляється в першому когнітивному слоті «Ггри з м'ячем» зі своїм розгалуженням слотів: «Футбол» $\mathrm{i}$ «Бейсбол» $\mathrm{i}$ другому когнітивному слоті «Водні види спорту» без додаткових розгалужень; третій когнітивний фрейм «Бігові змагання» втілений у двох когнітивних слотах, а саме: «Змагання з бігу» та «Похід». Розглянуто дискурсивні й метафоричні особливості всіх зазначених компонентів.

Ключові слова: метафорична концептуальна модель, концепт «Брекзит», концепт «спорт», політичний дискурс, метафора, концептуальна теорія ігор, когнітивний фрейм, слот. 